\title{
早播がパン用コムギ品種「ミナミノカオリ」の生地物性 および製パン適性に及ぼす影響
}

\author{
岩㴊哲也 ${ }^{1)} \cdot$ 田中浩平 ${ }^{2)} \cdot$ 松江勇次 $^{2)} \cdot$ 松中仁 ${ }^{3)} \cdot$ 山口末次 ${ }^{4)}$ \\ (1) 福岡県農業総合試験場豊前分場, ${ }^{2}$ 福岡県農業総合試験場, ${ }^{3)}$ 作物研究所, $\left.{ }^{4}\right)$ 元九州沖縄農業研究センター)
}

\begin{abstract}
要旨：北部九州におけるパン用コムギ品種「ミナミノカオリ」の早播が生地物性㧍よび製パン適性に及ぼす影響につ いて検討した。早播（11月上旬）は標準播（11月中旬〜下旬）と比べて,タンパク質含量には差がみられなかったが, 沈降量㧍よびグルテンインデックスが低かった，生地物性については，ファリノグラムにおける生地の形成時間や安 定度が短く，バロリメーターバリューが小さくなり，パン比容積が小さいため製パン適性は劣った。また，早播では， タンパク質組成のグルテニン含量と酢酸不溶性グルテニン含量が低かった，年次，播種期の異なるサンプルに拉いて， グルテニン含量は沈降量との間に, 酶酸不溶性グルテニン含量は沈降量およびグルテンインデックスとの間に有意な 正の相関関倸が認められた。したがって，早播で生地物性が弱く，製パン適性が劣った要因は，グルテニン含量㧍よ び酢酸不溶性グルテニン含量が低く，グルテンの質が低かったためであると考えられた。
\end{abstract}

キーワード：生地物性，製パン適性，タンパク質組成，早播，パン用コムギ，

国内産コムギは，大部分が日本めん用として用いられて きた。しかし，国内産コムギの生産量は日本めんの需要を 上回っているため, 新たな用途が求められている。近年, 消費者や製パン業者から国内産コムギを用いたパンを求め る声が高まってきており，この需要に応えるために，国内 産のパン用コムギ品種が育成されている（田谷ら 2003, 関 ら 2005)。しかし，その製パン適性は外国産に比べて劣る と言われてきた（尾関ら 1988，田谷ら 2003，関ら 2005）。

製パン適性とは，製パン時の作業性，パン体積抢よびパ ン品質についての評価であり,コムギ粉の生地物性が強い 程，製パン適性は高まることが知られている（池田 1961, 佐々木・長内 1969)。生地物性とは, コムギ粉生地の物理 的性状であり，ファリノグラフやエキステンソグラム等の 測定装置によって評価され，グルテンの質が高く，量が多 いほど生地物性は強いことが明らかにされている（佐藤ら 1999, 岩渕ら 2007).グルテンはグルテニンとグリアジン という貯蔵タンパク質から形成されて抢り,グルテニンの 弾性とグリアジンの粘性が生地物性に大きな影響を及ぼす (池田 2005)。グルテンの質は, 粘弾性の強さであり, 沈降 量（Takata ら 1999）やグルトマチックシステムによるグル テンインデックス（佐藤ら 2003, 岩渕ら 2007）等により 評価され, 高分子や低分子のグルテニンサブユニットの種 類が関与していることが報告されている（池田 2005, Tabiki ら 2006).

出穂期後に窒素を追肥すると, グルテン含量が増加して 生地物性が強くなり, 製パン適性が向上することが報告さ れている（佐藤ら 1999, 浦野·長嶺 2002, 佐藤 ·土屋 2004, 岩渕ら 2007). しかし, 出穂後の窒素追肥は成熟期 を遅らせてしまう（岩渕ら 2007）ので, 北部九州では, 梅 雨時期が収穫期と重なり, 降雨により品質が低下してしま
う恐れがある. 収穫期は, 早播栽培することで早めること ができることから，早播栽培が雨害を回避する一つの方法 になると考えられる。

これまで，北部九州に扔ける早播栽培は，10月下旬播種 のように極端に早播でない限り, 標準播栽培と同等の収量 を得ることができ（佐藤ら 2003，福嶌ら 2003），製粉特性 も変わらないことが明らかにされている（佐藤ら 2003）. しかし，早播栽培したパン用コムギ品種の製パン適性につ いての報告はない.

今後, 北部九州では, パン用コムギ品種についても出穂 後の追肥による品質向上とともに, 早播栽培により収穫期 の雨害回避を図らなければならないが, 広く普及させるた めには生産物の製パン適性が重要になる。

そこで, 本研究では, パン用コムギ品種「ミナミノカオ リ」の早播栽培が生地物性㧍よび製パン適性に及ぼす影響 を調査した。

\section{材料と方法}

試験は 2001～2002 年（播種年）に福岡県農業総合試験 場豊前分場（福岡県行橋市）で行ない, 供試品種は「ミナ ミノカオリ」とした，播種期は 2001 年は 11 月 9 日（早播 区)，11月 20 日(標準播区)，2002 年は 11 月 6 日(早播区), 11 月 19 日（標準播区）とした。播種量は，早播区で $\mathrm{m}^{2}$ 当たり出芽本数で 100 本, 標準播区で 150 本とした。栽培 方法は 4 条のドリル播（畦幅 $150 \mathrm{~cm}$, 条間 $30 \mathrm{~cm} ）$ とし, 踏圧と土入れは 2001 年の早播区は 1 月 10 日, 2 月 5 日, 標準播区は 2 月 5 日, 同 20 日, 2002 年の早播区は 1 月 7 日, 2 月 4 日, 標準播区は 2 月 4 日, 同 28 日に行った。試験 規模は 1 区 $9.0 \mathrm{~m}^{2}$ の 2 反復とした. $\mathrm{m}^{2}$ 当たり窒素施肥量 は基肥として 48 号（窒素・リン酸・加里を各 $16 \%$ 含有） 
第 1 表 早播が生育, 収量および外観品質に及ぼす影響.

\begin{tabular}{|c|c|c|c|c|c|c|c|c|c|c|}
\hline 播種年次 & 播種期 & 出穂期 & 成熟期 & $\begin{array}{l}\text { 倒伏 } \\
\text { 程度 }\end{array}$ & 穂数 & 粒数 & $\begin{array}{c}\text { 千粒 } \\
\text { 重 }\end{array}$ & $\begin{array}{c}\text { 容積 } \\
\text { 重 }\end{array}$ & 収量 & $\begin{array}{l}\text { 検査 } \\
\text { 等級 }\end{array}$ \\
\hline 年 & & 月。日 & 月. 日 & & 本 $\mathrm{m}^{-2}$ & 百粒 $\mathrm{m}^{-2}$ & g & $\mathrm{g}$ & $\mathrm{g} \mathrm{m}^{-2}$ & \\
\hline \multirow[t]{2}{*}{2001} & 早播 & 3.31 & 5.23 & 0.8 & 307 & 105 & 41.8 & 806 & 360 & 3.0 \\
\hline & 標準播 & 4.5 & 5.29 & 0.5 & 319 & 116 & 40.6 & 803 & 368 & 3.5 \\
\hline \multirow[t]{2}{*}{2002} & 早播 & 4.7 & 5.30 & 1.5 & 329 & 116 & 38.2 & 793 & 378 & 7.0 \\
\hline & 標準播 & 4.13 & 6.5 & 1.0 & 344 & 141 & 39.6 & 803 & 445 & 7.0 \\
\hline \multirow[t]{5}{*}{ 平均 } & 早播 & 4.4 & 5.26 & 1.1 & 318 & 111 & 40.0 & 799 & 369 & 5.0 \\
\hline & 標準播 & 4.9 & 6.1 & 0.8 & 331 & 128 & 40.1 & 803 & 406 & 5.3 \\
\hline & 播種期 & - & - & $*$ & ns & ns & ns & ns & ns & ns \\
\hline & 年次 & - & - & $* *$ & ns & ns & * & $*$ & ns & $* *$ \\
\hline & 播種期 $\times$ 年次 & - & - & ns & ns & $\mathrm{ns}$ & ns & $*$ & ns & ns \\
\hline
\end{tabular}

倒伏程度は，０（無倒伏）～5（完全倒伏）の 6 段階で, 成熟期頃に達観調査した.

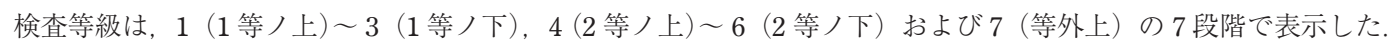

*，**はそれぞれ $5,1 \%$ 水準で有意であり，nsは有意でないことを示す，

を $5.0 \mathrm{~g}$, 第 1 回追肥として本葉 5 葉期（2001 年の早播区 は 1 月 9 日, 標準播区は同 25 日，2002年の早播区は同 7 日, 標準播区は 2 月 4 日）に NK 化成 2 号（窒素・加里を各 $16 \%$ 含有）を $4.0 \mathrm{~g}$, 第 2 回追肥として主秙の幼穂長が約 $2 \mathrm{~mm}$ の時期（2001 年の早播区は 2 月 7 日，標準播区は同 20 日，2002 年の早播区は同 14 日，標準播区は同 28 日） にNK 化成 2 号を $2.0 \mathrm{~g}$, 第 3 回追肥として出穂後約 10 日 の開花期頃（2001 年の早播区は 4 月 10 日，標準播は同 18 日，2002 年の早播区は同 18 日，標準播区は同 23 日）に硫 安（窒素を $21 \%$ 含有） $4.0 \mathrm{~g}$ を施用した。

生育については, 出穂期, 成熟期, 穂数, 粒数および倒 伏程度の調査を行うとともに, 粒厚 $2.0 \mathrm{~mm}$ 以上の子実に ついて, 子実収量, 千粒重, 容積重および検査等級の調査 を行った。なお，容積重はブラウエル穀粒計によって測定 した。刚取面積は $3.0 \sim 6.0 \mathrm{~m}^{2}$ とした。

製粉はブラベンダーテストミルにより行い，A 粉を品質 試験に供試した。製粉および品質分析は小麦品質検定方法 （農林水産技術会議事務局 1968）に準じて行った。粉の夕 ンパク質含量はケルダール法により求めた全窒素にタンパ ク質換算係数 5.7 を乗じて求めた。 コムギ粉の糊化特性 についてはフォーリングナンバー值と最高粘度を測定し た.フォーリングナンバー值は, 子実を粉砕した粉 $7 \mathrm{~g}$ （水 分含量を $15 \%$ に換算）について，フォーリングナンバー 1800 （Falling Number 社）により測定した。最高粘度は, ラピッドビスコアナライザー（Newport Scientific 社製）に より牛山ら（1997）の方法に準じて測定した。生地物性に ついては, 小麦品質検定方法に従って, ファリノグラムの 測定值から吸水率を算出するとともに，得られた図形から 生地の形成時間, 安定度, 弱化度およびバロリメーターバ リュー（生地物性の総合評価值）を求めた。なお，パン用 コムギでは一般的に吸水率が高く，生地の形成時間と安定 度が長く, 弱化度が小さく, バロリメーターバリューが大 きい. また，グルテンの質を示すグルテンインデックス，
グルテンの含量を示す湿グルテンはグルトマチックシステ ム (Falling Number 社) により測定した. グルテンインデッ クス，湿グルテンは值が高いほどグルテンの質および含量 が高い.グルテンの質および量を表す沈降量はSDS- セディ メンテーションテストにより, Takataら（1999）の方法を もとに，供試量を $\mathrm{A}$ 粉 $1.0 \mathrm{~g}$, 膨潤時間を 24 時間として 行った。沈降量はグルテンの質および量を表し, 大きいほ どグルテンの質が高く，グルテン含量が高い.

タンパク質の分画は, 佐藤ら（1999）の方法にもとづい て行った. A 粉 $3 \mathrm{~g}$ に $0.5 \mathrm{M}$ 塩化ナトリウム $(\mathrm{NaCl})$ 溶液 $30 \mathrm{~mL}$ を加え, $4 \pm 1^{\circ} \mathrm{C}$ の恒温機内で 2 時間擋拌し, 遠心分 離 $(13,000 \times \mathrm{g}, 10$ 分）によって上澄みを回収した。残椬 から $\mathrm{NaCl}$ 溶液 $30 \mathrm{~mL}$ で抽出を 2 回 $(2$ 時間 $\times 1 ， 1$ 時間 ×1回）繰り返し,上澄みを合わせて, アルブミン +グロ ブリン画分を得た。この残椬を $70 \%$ エタノールで同様に 3 回抽出し，上澄みを合わせてグリアジン画分を得た。さら に残椬を $0.02 \mathrm{M}$ 水酸化ナトリウム $(\mathrm{NaOH})$ 溶液 25,15 , $8 \mathrm{~mL}$ で同様に 3 回抽出し, グルテニン画分を得た。グル テニン液 $25 \mathrm{~mL}$ に $10 \%$ トリクロロ酢酸（TCA）溶液 $10 \mathrm{~mL}$ を加え, 30 分間覺拌し遠心分離してグルテニンの沈殿を 得た。これら分画した溶液の全窒素を分析し, タンパク質 換算係数 5.7 を乗じて各分画の含量を求めた. なお, 酢 酸不溶性グルテニン含量はグルテニン含量から酢酸可溶性 グルテニン含量を差し引いて算出した.

製パン試験は 2004 年 3 月に九州沖縄農業研究センター 水田研究利用部 (福岡県筑後市) において, A 粉を供試して, 前報（岩渕ら 2007）と同様に行ない, パン比容積を測定し た。パン比容積は高いほど製パン適性が高い.

\section{結果}

\section{1. 早播が生育, 収量および外観品質に及ぼす影響}

第 1 表に早播が生育, 収量および外観品質に及ぼす影響 を示した。早播区は標準播区と比べて, 出穂期が $5 〜 6$ 日, 
第 2 表 早播がフォーリングナンバー值，最高粘度，A 粉タンパク質含量，グルテンの質・含量に及ぼす影響.

\begin{tabular}{|c|c|c|c|c|c|c|c|}
\hline 播種年次 & 播種期 & $\begin{array}{c}\text { フォーリング } \\
\text { ナンバー值 }\end{array}$ & 最高粘度 & $\begin{array}{c}\mathrm{A} \text { 粉タンパク } \\
\text { 質含量 }\end{array}$ & 沈降量 & $\begin{array}{c}\text { グルテン } \\
\text { インデックス }\end{array}$ & 湿グルテン \\
\hline 年 & & 秒 & $\mathrm{BU}$ & $\%$ & $\mathrm{~mL}$ & $\%$ & $\%$ \\
\hline \multirow[t]{2}{*}{2001} & 早播 & 426 & 277 & 12.0 & 11.8 & 78.8 & 38.5 \\
\hline & 標準播 & 436 & 270 & 11.7 & 12.6 & 86.5 & 39.0 \\
\hline \multirow[t]{2}{*}{2002} & 早播 & 406 & 267 & 11.9 & 11.4 & 73.4 & 38.2 \\
\hline & 標準播 & 378 & 276 & 12.1 & 12.9 & 82.8 & 39.8 \\
\hline \multirow[t]{5}{*}{ 平均 } & 早播 & 416 & 272 & 12.0 & 11.6 & 76.1 & 38.3 \\
\hline & 標準播 & 407 & 273 & 11.9 & 12.8 & 84.6 & 39.4 \\
\hline & 播種期 & ns & ns & $\mathrm{ns}$ & + & + & ns \\
\hline & 年次 & + & ns & ns & ns & ns & ns \\
\hline & 播種期 $\times$ 年次 & ns & ns & ns & ns & ns & ns \\
\hline
\end{tabular}

+は 10\%水準で有意であり, ns は有意でないことを示す.

第 3 表＼cjkstart早播がタンパク質組成に及ぼす影響.

\begin{tabular}{|c|c|c|c|c|c|}
\hline 播種年次 & 播種期 & $\begin{array}{l}\text { Pルブミン } \\
+ \text { +グロブリン }\end{array}$ & グリアジン & グルテニン & $\begin{array}{l}\text { 酢酸不溶性 } \\
\text { グルテニン }\end{array}$ \\
\hline 年 & & $\%$ & $\%$ & $\%$ & $\%$ \\
\hline \multirow[t]{2}{*}{2001} & 早播 & 2.6 & 4.2 & 4.5 & 1.4 \\
\hline & 標準播 & 2.6 & 4.1 & 4.8 & 1.7 \\
\hline \multirow[t]{2}{*}{2002} & 早播 & 2.7 & 4.1 & 4.6 & 1.3 \\
\hline & 標準播 & 2.5 & 4.0 & 4.9 & 1.5 \\
\hline \multirow[t]{5}{*}{ 平均 } & 早播 & 2.6 & 4.1 & 4.5 & 1.4 \\
\hline & 標準播 & 2.5 & 4.1 & 4.8 & 1.6 \\
\hline & 播種期 & ns & ns & + & + \\
\hline & 年次 & ns & $\mathrm{ns}$ & ns & ns \\
\hline & 播種期 $\times$ 年次 & ns & ns & ns & ns \\
\hline
\end{tabular}

+は 10\%水準で有意であり, ns は有意でないことを示す.

成熟期は 6 日早く, 倒伏程度は大きくなった，収量，容積 重および検査等級に有意な差は認められなかった。

\section{2. 早播がフォーリングナンバー值, 最高粘度, A 粉タ} ンパク質含量, グルテンの質・含量およびタンパク質 組成に及ぼす影響

第 2 表に早播がフォーリングナンバー值，最高粘度，A 粉タンパク質含量およびグルテンの質・含量に及ぼす影響 を示した。 フォーリングナンバー值, 最高粘度, A 粉夕ン パク質含量および湿グルテンに播種期による差はみられな かったが，早播区は標準播区と比べて，沈降量とグルテン インデックスが 2 カ年平均でそれぞれ $11.6 \mathrm{~mL} ， 76.1 \%$ と低く，グルテンの質が低かった．

次に，第 3 表に早播がタンパク質組成に及ぼす影響を示 した。早播区は標準播区と比べて，タンパク質組成のアル ブミン+グロブリン含量とグリアジン含量には差が認めら れなかったが, グルテニン含量と酢酸不溶性グルテニン含 量が 2 力年平均でそれぞれ $4.5 \%, 1.4 \%$ と少なく, 播種 期による差が認められた。

\section{3. 早播が生地物性やパン比容積に及ぼす影響}

第 4 表に早播が生地物性やパン比容積に及ぼす影響を示 した．早播区は標準播区と比べて，ファリノグラムの吸水 率は同程度であったが，生地の形成時間および生地の安定 度が平均でそれぞれ 4.8 分, 6.0 分と短く, 弱化度が $83.8 \mathrm{BU}$ と大きく，バロリメーターバリューが 56.8 であ り，パン比容積は $4.3 \mathrm{~mL} \mathrm{~g}^{-1}$ と小さかった.

\section{A 粉タンパク質含量, タンパク質組成とグルテンの質・} 含量, 生地物性, パン比容積との関係

第 5 表に A 粉タンパク質含量, タンパク質組成とグルテ ンの質・含量, バロリメーターバリューおよびパン比容積 との相関係数を示した.

$\mathrm{A}$ 粉タンパク質含量およびアルブミン＋グロブリン含量 はどの形質との間においても有意な相関関係は認められな かった。一方, グリアジン含量は湿グルテンとの間に, グ ルテニン含量は沈降量, バロリメーターバリューおよびパ ン比容積との間に有意な正の相関関係が認められた。また, 酢酸不溶性グルテニン含量は沈降量, グルテンインデック 
第 4 表＼cjkstart早播が生地物性およびパン比容積に及ぼす影響。

\begin{tabular}{|c|c|c|c|c|c|c|c|}
\hline \multirow{2}{*}{ 播種年次 } & \multirow{3}{*}{ 播種期 } & \multicolumn{5}{|c|}{ ファリノグラム } & \multirow{2}{*}{ パン比容積 } \\
\hline & & $\mathrm{Ab}$ & DT & Stab & Wk & V.V. & \\
\hline 年 & & $\%$ & 分 & 分 & $\mathrm{BU}$ & & $\mathrm{mL} \mathrm{g}^{-1}$ \\
\hline \multirow[t]{2}{*}{2001} & 早播 & 66.0 & 5.2 & 6.4 & 82.5 & 58.5 & 4.2 \\
\hline & 標準播 & 65.6 & 6.5 & 9.3 & 50.0 & 67.0 & 4.6 \\
\hline \multirow[t]{2}{*}{2002} & 早播 & 66.0 & 4.4 & 5.6 & 85.0 & 55.0 & 4.4 \\
\hline & 標準播 & 63.7 & 6.7 & 8.9 & 67.5 & 66.0 & 4.6 \\
\hline \multirow[t]{5}{*}{ 平均 } & 早播 & 66.0 & 4.8 & 6.0 & 83.8 & 56.8 & 4.3 \\
\hline & 標準播 & 64.6 & 6.6 & 9.1 & 58.8 & 66.5 & 4.6 \\
\hline & 播種期 & ns & $*$ & $*$ & $*$ & $* *$ & + \\
\hline & 年次 & ns & ns & ns & ns & ns & ns \\
\hline & 種期 $\times$ 年次 & $\mathrm{ns}$ & $\mathrm{ns}$ & ns & ns & ns & ns \\
\hline
\end{tabular}

Ab は吸水率, DT は生地の形成時間, Stab は生地の安定度, Wk は弱化度, V.V. はバロリメーターバリューを示す. ,$+ *$ ***はそれぞれ $10,5,1 \%$ 水準で有意であり, ns は有意でないこと示す.

第 5 表 $\mathrm{A}$ 粉タンパク質含量, タンパク質組成とグルテンの質・含量, 生地物性, パン比容積との相関係数.

\begin{tabular}{cccccc}
\hline & $\mathrm{SV}$ & $\mathrm{GI}$ & $\mathrm{WG}$ & V.V. & 比容積 \\
\hline タンパク & $0.38 \mathrm{~ns}$ & $0.01 \mathrm{~ns}$ & $0.35 \mathrm{~ns}$ & $0.13 \mathrm{~ns}$ & $0.44 \mathrm{~ns}$ \\
$\mathrm{AB}+\mathrm{GB}$ & $-0.01 \mathrm{~ns}$ & $0.02 \mathrm{~ns}$ & $-0.07 \mathrm{~ns}$ & $-0.24 \mathrm{~ns}$ & $0.06 \mathrm{~ns}$ \\
$\mathrm{GA}$ & $0.55 \mathrm{~ns}$ & $0.30 \mathrm{~ns}$ & $0.74^{*}$ & $0.27 \mathrm{~ns}$ & $0.61 \mathrm{~ns}$ \\
$\mathrm{GT}$ & $0.65+$ & $0.34 \mathrm{~ns}$ & $0.35 \mathrm{~ns}$ & $0.73^{*}$ & $0.64+$ \\
$\mathrm{NGT}$ & $0.81^{*}$ & $0.77^{*}$ & $0.26 \mathrm{~ns}$ & $0.82^{*}$ & $0.59 \mathrm{~ns}$ \\
\hline
\end{tabular}

タンパクは $\mathrm{A}$ 粉タンパク質含量, $\mathrm{AB}+\mathrm{GB}$ はアルブミン+グロブリン, $\mathrm{GA}$ はグリアジン, $\mathrm{GT}$ はグルテニン NGT は酢酸不溶性グルテニン, SV はSDS- セデイメンテーションテストの沈降量, GI はグルテンインデックス, WG は湿グルテン, V.V.はバロリメーターバリューおよび比容積はパン比容積を示す.

$2001 \sim 2002$ 年の全区を込みにして解析を行った $(\mathrm{n}=8)$.

+,*はそれぞれ 10，5\%水準で有意であり，ns は有意でないことを示す。

スおよびバロリメーターバリューとの間に有意な正の相関 関係が認められた。

また, グルテンの質とバロリメーターバリューおよびパ ン比容積との関係では, 沈降量とバロリメーターバリュー $\left(\mathrm{r}=0.86^{* *}\right)$ およびパン比容積 $(\mathrm{r}=0.80 *)$ との間に, グルテンインデックスとバロリメーターバリュー（r= $0.72 *)$ との間に有意な正の相関関係が認められた。

\section{考察}

早播は標準播に比較して，ファリノグラムのバロリメー ターバリューやパン比容積が小さく, 生地物性が弱く, 製 パン適性は劣った。また，A 粉タンパク質含量および湿グ ルテンは差がみられなかったが, 沈降量やグルテンイン デックスは小さく，グルテンの質は低かった。沈降量とバ ロリメーターバリューおよびパン比容積との間に, グルテ ンインデックスとバロリメーターバリューとの間に有意な 正の相関関係が認められており，これは，グルテンの質が 高ければ, 生地物性が強く, パン比容積が大きくなること を示す.

グルテンの質が低い品種・系統はタンパク質含量が高く
ても製パン適性が劣ることが指摘されている（池田 1961, 佐々木・長内 1969 , 尾関ら 1988, 岩㴊ら 2007)。したがっ て，早播は A 粉タンパク質含量に標準播との差がないにも かかわらず，生地物性が弱く，パン比容積が小さかった一 つの要因は, グルテンの質が標準播より低かったためであ ると推察される。

本研究において，早播ではグルテニン含量および酢酸不 溶性グルテニン含量が低く, 生地物性が弱く, パン比容積 が小さかった。これは, グルテニン含量と生地物性および パン比容積との間には有意な正の相関関係がみられること （佐藤ら 1999），製パン適性にはグルテニンの影響が大きい こと（Branlardら 2001），製パン適性に優れる品種は酢酸 不溶性グルテニン含量が高いこと（Orth and Bushuk 1972） という報告と一致した。 また，グルテニン含量は沈降量と の間に，酢酸不溶性グルテニン含量は沈降量およびグルテ ンインデックスとの間に有意な正の相関関係が認められ た。これは，グルテン含量や酢酸不溶性グルテニン含量が 多いとグルテンの質が高まることを示す。よって，播種期 の違いによるグルテンの質の差はグルテニン含量および酢 酸不溶性グルテニン含量の差であると考えられる. 
早播では生育後期に窒素が不足することが報告されてい る（吉田ら 1969）。グルテニンなどの貯蔵タンパクは比較 的遅く蓄積されることが報告されており（Triboïら 2003）, 早播でグルテニン含量が少なかった要因は, 生育後期の窒 素不足である可能性がある。

本研究において，早播ではグルテニン含量および酢酸不 溶性グルテニン含量が低く，グルテンの質が低く，製パン 適性が劣ることが明らかになった。このため，早播を前提 とした製パン適性の優れるコムギを生産するためには，早 播でもグルテニン含量および䣷酸不溶性グルテニン含量が 高くなる栽培法の確立が必要である。Triboïら（2003）は 子実肥大期の窒素吸収量の増加により，グルテニンなどの 貯蔵タンパクが増加することを報告しており, 窒素施用法 により, グルテニン含量を増加させることができる可能性 がある。

今後は, 栽培環境とグルテニン含量および酢酸不溶性グ ルテニン含量との関係を明らかにして，グルテニン含量お よび酢酸不溶性グルテニン含量を高めることによって, グ ルテンの質を向上させる栽培方法を確立する必要がある。

謝辞：製粉機や分析機器の使用にあたりご指導ご助言を 頂いた作物研究所小麦研究グループの皆様，製パンにあた りご指導ご助言を頂いた九州沖縄農業研究センター筑後研 究拠点小麦 · 大麦育種ユニットの皆様に厚く御礼申し上げ ます.

\section{引用文献}

Branlard, G., M. Dardevet, R. Saccomano, F. Lagoutte and J. Gourdon 2001. Genetic diversity of wheat storage proteins and bread wheat quality. Euphytica $119: 59-67$.

福嶌陽・楠田宰・古畑昌己 2003. 暖地における早播きした秋播性コ ムギ「イワイノダイチ」の収量成立要因の解析. 日作紀 $72: 149-$ 157.

池田達哉 2005. 生地物性を支配する低分子量グルテニン・サブユ ニット.冬作物研究 $5: 9-16$.

池田利良 1961. 日本に押ける硬質小麦の研究. 東海近畿農試特報 栽 培 $12: 1-55$.

岩渕哲也 · 田中浩平 · 松江勇次 - 松中仁 - 山口未次 2007. 開花期の 窒素追肥がパン用コムギ品種「ミナミノカオリ」と「ニシノカオ リ」の製粉性，生地の物性および製パン適性に及ぼす影響. 日作
紀 $76: 37-44$.

農林水産技術会議事務局 1968. 小麦品質検定方法 - 小麦育種試験に おけるー。研究成果シリーズ $35: 1-70$.

Orth, R.A. and W. Bushuk 1972. A comparative study of the proteins of wheats of diverse baking qualities. Cereal Chem. $49: 268-275$.

尾関幸男 · 佐々木宏 · 天野洋一 ·土屋俊雄 - 前野真司 $\cdot$ 上野賢司 1988. 春播小麦新品種「ハルユタカ」の育成について. 北海道立農 試集報 $58: 41-54$.

佐々木宏・長内俊一 1969. 硬質春播小麦のパン適性と収量の選抜実 験 第 I 報選抜形質とパン適性. 北海道立農試集報 19:21-35.

佐藤暁子・小綿美環子・中村信吾・渡辺満 1999. コムギの製パン適 性に及ぼす窒素追肥時期の影響. 日作紀 $68: 217-223$.

佐藤大和 · 内村要介・松江勇次 2003. コムギにおける播種時期の違 いが製粉特性に及ぼす影響. 日作紀 $72: 43-49$.

佐藤導謙・土屋俊雄 2004. 北海道中央部に扔ける春播コムギの初冬 播栽培に関する研究一窒素施用法が製パン品質に及ぼす影響－ . 日作紀 $73: 282-286$.

関昌子 - 八田浩一 波多野哲也 - 河田尚之 - 氏原和人 - 佐々木昭博 田谷省三 · 堤忠宏 - 藤田雅也 - 谷口義則 - 塔野岡卓司 - 坂智広 . 平将人 2005. 小麦新品種「ミナミノカオリ」の主要特性. 九農研 $67: 13$.

Tabiki, T., S. Ikeguchi and T.M. Ikeda 2006. Effects of high-molecularweight and low-molecular-weight glutenin subunit alleles on common wheat flour quality. Breed. Sci. 56 : $131-136$.

Takata, K., H. Yamauchi, N. Iriki and T. Kuwabara 1999. Prediction of bread-making quality by prolonged swelling SDS-sedimentation test. Breed. Sci. $49: 221-223$.

田谷省三 · 塔野岡卓司 - 関昌子 · 平将人 · 堤忠宏 - 野中舜二 ・ 氏原 和人 · 佐々木昭博 - 山口勲夫 · 新本英二 · 吉川亮 - 藤田雅也 · 谷 口義則 ·坂智広 2003 . 小麦新品種「ニシノカオリ」の育成. 九沖 農研七報 $42: 19-30$.

Triboï, E., M. Pierre and A.-M. Triboï-Blondel 2003. Environmentallyinduced changes in protein composition in developing grains of wheat are related to changes in total protein content. J. Exp. Bot. 54 : 1731 -1742 .

浦野光一郎・長嶺敬 2002. 出穂後窒素追肥技術を適用したパン用小 麦有望系統の栽培・加工特性. 日作中国支集録 $43: 24-25$.

牛山智彦·倉島稔・細野哲 · 久保田基成 1997. 小麦粉アミログラフ 值の簡易迅速法の検討. 北陸作物学会報 $32: 105-106$.

吉田美夫 · 北原操一 - 鶴政夫 1969. 小麦のは種適期と作季の移動に ついて. 九農研 $31: 51-52$. 
Effects of Early Sowing on Physical Dough Characteristics and Bread-Making Quality of Bread Wheat Cultivar "Minaminokaori" : Tetsuya Iwabuchi ${ }^{1)}$, Kohei Tanaka ${ }^{2}$, Yuji Matsue ${ }^{2}$, Hitoshi Matsunaka ${ }^{3)}$ and Suetsugu Yamaguchi ${ }^{4)}\left({ }^{1)}\right.$ Fukuoka Agr. Res. Cent. Buzen Br., Yukuhashi, 824-0038, Japan ; ${ }^{2}$ Fukuoka Agr. Res. Cent. ; ${ }^{3)}$ Natl. Agr. Res. Cent. Crop Science ; ${ }^{4)}$ Retired Natl. Agr. Res. Cent. Kyushu Okinawa Region)

Abstract : The effects of early sowing on physical dough characteristics and bread-making quality of bread wheat cultivar "Minaminokaori" were investigated in Northern Kyusyu. The protein content of flour did not vary with the sowing time, but the sedimentation value and gluten index were lower in early sowing (early November) than in standard sowing (middle-late November). The dough development time, stability, valorimeter value of farinogram and volume-to-weight ratio of loaf were lower in early sowing than in standard sowing, and therefore the physical dough characteristics and bread-making quality in early sowing were inferior to those in standard sowing. Furthermore, glutenin and acetic acid-insoluble glutenin contents were lower in early sowing than in standard sowing. The glutenin content was positively correlated with sedimentation value and acetic acidinsoluble glutenin content was positively correlated with sedimentation value and gluten index. These results suggested that one of the reasons why physical dough characteristics and bread-making quality in early sowing were inferior to those in standard sowing was that glutenin and acetic acid-insoluble glutenin contents in early sowing were lower than those in standard sowing, and therefore the quality of gluten in early sowing was inferior to that in standard sowing.

Key words : Bread-making quality, Bread wheat, Early sowing, Physical dough characteristics, Protein composition. 